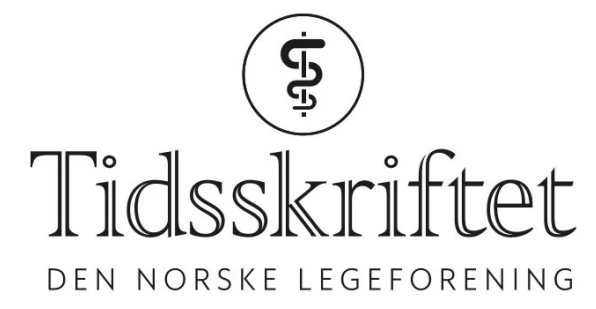

\title{
Prostaglandiner kan påvirke både hjerne og muskler
}

FRA ANDRE TIDSSKRIFTER

HAAKON B. BENESTAD

Universitetet i Oslo

Inflammasjonsmediatoren prostaglandin $\mathrm{E}_{2}$ kan ha negativ effekt på kognitive evner, men positiv effekt på muskelstyrke hos gamle mus.

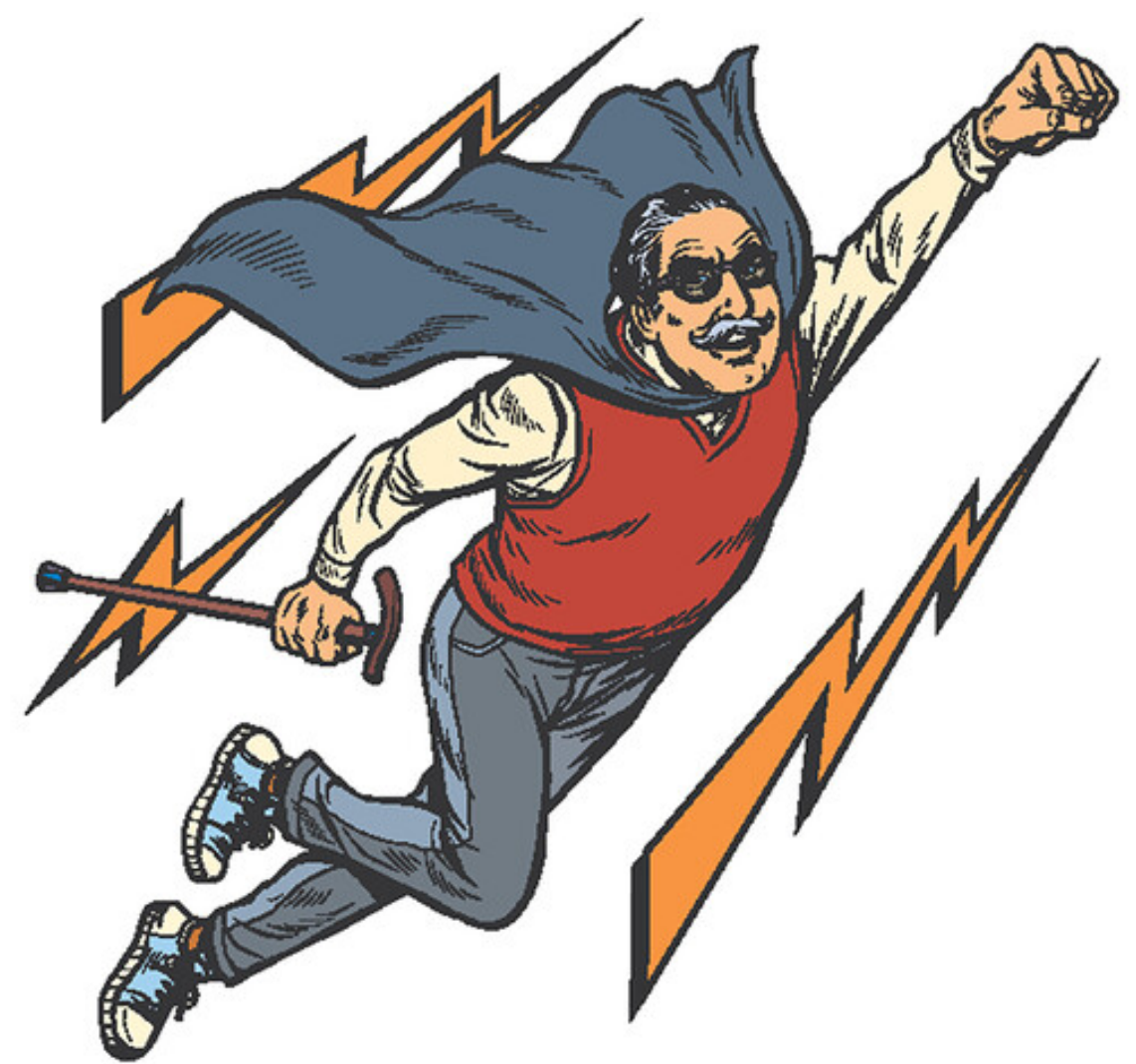

Illustrasjon: Valeriy Kachaev / NTB 
Aldring medfører kronisk inflammasjon, som bidrar til utvikling av arteriosklerose, metabolsk syndrom og kognitivt forfall. Derfor kan det tenkes at hemming av inflammasjonsmediatorer med legemidler kan motvirke aldring. To nye studier viser at inflammasjonsmediatoren prostaglandin $\mathrm{E}_{2}$ kan ha spesielle effekter på både kognisjon (1)

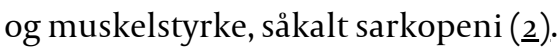

I den første studien med vanlige makrofager og hjernens mikroglia fra gamle mennesker og mus stimulerte prostaglandin $\mathrm{E}_{2}$, via en oppregulert inflammatorisk EP2-reseptor, lagring av glukose i glykogen, mens glykolyse og mitokondrierespirasjon ble redusert (1) . Sviktende cellulær energiproduksjon ble forverret av at gamle makrofager er avhengige av glukose. Disse inflammatoriske makrofagene ble drivere av kronisk inflammasjon og kognitivt forfall. Hemming av prostaglandin $\mathrm{E}_{2}$-signaleringen, farmakologisk eller ved å slå ut reseptor-EP2-genet, økte makrofagenes ATP-dannelse, reduserte inflammasjon både systemisk og i hjernen samt polariserte makrofagene henimot renovasjonstypen. Dessuten økte hippocampus' synapseplastisitet og musenes romlige hukommelse.

I den andre studien hadde nedsatt prostaglandin $\mathrm{E}_{2}$-effekt betydning for sarkopeni hos gamle mus ( $\underline{2}$ ). Prostaglandin $\mathrm{E}_{2}$ er en viktig aktivator av anabol metabolisme, via reseptoren $\mathrm{EP}_{4}$, for stamcellefunksjon og for regenerasjon i forskjellige vev, bl.a. skjelettmuskelvev. Med alderen økte musene produksjonen av enzymet 15hydroksyprostaglandin-dehydrogenase i muskler og i deres makrofager via kartlagte cellulære signalveier. $\emptyset \mathrm{kt}$ dehydrogenase $\emptyset \mathrm{kte}$ nedbrytningen av prostaglandin $\mathrm{E}_{2}$ med nedsatt proteinsyntese i musklene, økt proteasomdegradering av proteiner og nedsatt autofagi, med tydelig mitokondrieskade ved elektronmikroskopi. Ved å hemme dehydrogenasen farmakologisk eller ved å slå ut genet ble prostaglandin $\mathrm{E}_{2}$-signaleringen restituert, slik at mitokondriefunksjonen, utholdenheten på tredemølle og muskelsvekkelsen ble bedret i løpet av en måneds tid.

- Man kan teoretisk se for seg at en selektiv EP2-antagonist kan bidra til å bevare gode kognitive evner, mens de som vil beholde god muskelstyrke, heller vil ønske seg en selektiv EP4-agonist, sier Guttorm Haraldsen, som er professor i patologi ved Det medisinske fakultet, Universitetet i Oslo. Han mener at en vanlig, men ikke veldig god innvending, er at man ikke kan manipulere den brede effekten av prostaglandiner. Utviklingen av JAK/STAThemmere har nemlig ført til innovativ utvikling av effektive medikamenter, selv om nullmutasjon av samtlige JAK-isoformer er letale under embryogenesen, sier Haraldsen.

\section{LITTERATUR}

1. Minhas PS, Latif-Hernandez A, McReynolds MR et al. Restoring metabolism of myeloid cells reverses cognitive decline in ageing. Nature 2021; 590: 122-8. [PubMed][CrossRef]

2. Palla AR, Ravichandran M, Wang YX et al. Inhibition of prostaglandin-degrading enzyme 15-PGDH rejuvenates aged muscle mass and strength. Science 2021; 371: eabc8059. [PubMed][CrossRef]

Publisert: 29. april 2021. Tidsskr Nor Legeforen. DOI: 10.4045/tidsskr.21.0208

(C) Tidsskrift for Den norske legeforening 2023. Lastet ned fra tidsskriftet.no 26. april 2023. 